\title{
ASSESSMENT OF LEAD, CADMIUM AND SELENIUM LEVELS IN SOME DRIED MILK SOLD IN MARKETS
}

\author{
AHMED ABDEL-HAMEID AHMED ${ }^{1}$, WALLAA FAROUK AMIN ${ }^{1}$, MANAL M. AMIN ${ }^{2}$ AND \\ RASHA FAWZY EID GHETANY ${ }^{2}$ \\ ${ }^{1}$ Food Hygiene Department, Faculty of Veterinary Medicine, Assiut University, Assiut, Egypt. \\ ${ }^{2}$ Food Hygiene Department, Animal Health Research Institute, Assiut Branch Egypt.
}

Received: 30 December 2019; Accepted: 31 January 2020

\begin{abstract}
Dairy products samples were contaminated with variable amounts of heavy metals. Drinking water used to mix infant powdered formula may add cadmium and lead significantly to the concentrations in the ready-made products. The presence of heavy metals in human's diet even in low level, can lead to presence of these metals in human's body by considerable concentration. Metals that cannot be metabolized (as cadmium and lead), persisted in the body and exerted their toxic effect by combining with one or more reactive group essential for normal physiological function and cellular disturbance or clinical manifestations may be appeared. Hence, seventy random samples of some dried milk products (infant powdered milk based formulae) were collected from different markets and pharmacies in Assiut Governorate, Egypt. These samples were collected in their original containers and packets, and transported to the laboratory for estimation of lead (pb), cadmium (cd) and selenium (se) levels. The digest, blanks and standard solutions were aspirated by Atomic Absorption Spectrophotometer (VARIAN, model AA240 FS, Australia). The percentage of positive samples for lead, cadmium and selenium was 60, 51.4 and 100\%, respectively, in the first type and 48.6, 40 and $100 \%$, respectively, in the second type. The results of positive samples that exceeded the MPL for lead, cadmium and selenium showed in the first type 76.2, 72.2 and $17.1 \%$, respectively, and in the second type 82.4, 57.1 and 2.9\%, respectively. The values of the quantities measured weekly (EWI) for lead, cadmium and selenium were in the first type according to the averages $7.546,4.312$ and $0.973 \mathrm{mg} / \mathrm{kg}$ of body weight, respectively, while the second type was $3.675,1.652$ and $0.553 \mathrm{mg} / \mathrm{kg}$ of body weight.
\end{abstract}

Keywords: Heavy metals, infant powdered formula, lead, cadmium, selenium, toxic effect.

\section{INTRODUCTION}

Despite the benefits of infant formulas as a major source of food for infants, the presence of contaminants, such as heavy metals, may pose health risks to children. It has been reported that children are more susceptible to exposure (Tripathi et al., 1999) because of their greater intestinal absorption than adults, and a lower threshold for adverse effects (Cambra and Alonso, 1995). These pollutants may arise from the raw materials used in production, poor quality production process, adulteration of infant foods, contamination of the original cow's milk, which may be due to exposure of lactating cow to environmental pollution or consumption of contaminated feeding stuffs and water (Carl, 1991; Okada et al., 1997). Contamination may also occur

Corresponding author: Dr. Manal M. Amin E-mail address: manalamin727@yahoo.com Present address: Food Hygiene Department, Animal Health Research Institute, Assiut Branch Egypt from the use of aluminum utensils and cans for milk and dairy products (De Voto and Yokel, 1994; Masten, 2000).

Although the main quality parameters for infant milk formula are the microbiological and sensory characteristics, recent investigations have been recommended that the determination of heavy metals and trace elements in infant milk formula should be included to these parameters. (Karadjova et al., 2000; Martino et al., 2000; Orak et al., 2005).

The presence of toxic heavy metals as cadmium and lead even in low concentrations, leads to metabolic disorders and serious health problems such as weakness, heart failure, cancer and also affects the kidneys (Licata et al., 2004). Heavy metals are toxic because they may have cumulative deleterious effects that can cause chronic degenerative changes (Amer et al., 2006).

Heavy metals are persistent as contaminants in the environment and come to the fore front of dangerous 
substances causing health hazards in human. Lead $(\mathrm{Pb})$ and cadmium $(\mathrm{Cd})$ are among the most common of these elements. Industrial and agricultural processes have resulted in an increased concentration of heavy metals in air, water, soil and subsequently, these metals are taken by plants or animals and find their ways into food chain (Ahmad, 2002).

Among the metals found in the human body, only a small number are believed to be essential as selenium (Se) (Lopez-Garcia et al., 2009). Deficiency of any one of essential metal nutrients will result in specific biochemical lesions within cells of the body and subsequently development of certain characteristic clinical symptoms which will normally alleviate when the deficiency is corrected by supplying an adequate amount of the missing element. Although these metals are essential for health, excessive exposure may be hazardous (Protasowicki, 1992; Akhter et al., 2004). This is complicated even further if there is a very narrow range between the concentration at which metal is considered essential and considered toxic (Higharm and Tomkins, 1993).

Selenium acts as a protective agent against heavy metal toxicity (Anderson and Nielsen, 1993), cancer (Helzlsouer et al., 1989) and cardiovascular diseases (Korpela, 1993).

For infants and children, however, the core of Seproviding foods may be much smaller. The selenium intake of infants is of interest because of their rapid growth rate and their heavy reliance on milk, a food that has a highly variable selenium content, depending on its geographical origin. At six months of age, milk provided only $35 \%$ of the total dietary Se. By 12 months of age, the introduction of a variety of foods further decreased the relative contributions of milk to the Se nutrition of the infants. Selenium concentration in milk formula is generally lower than in breast milk (Lombeck 1980; Litov et al., 1987). Others have also shown that selenium levels double from early infancy to adult life (Hatano et al., 1984). So, this study aimed to determine the incidence and levels of lead, cadmium and selenium in infant powdered milk-based formulae.

\section{MATERIALS AND METHODS}

\section{Collection of samples:}

A total of 70 random samples of locally packaged infants powdered milk based formula were purchased from different markets and pharmacies in Assiut Governorate, Egypt. The collected samples were examined for determination of their lead, cadmium and selenium levels on the basis of wet weight $(\mathrm{mg} / \mathrm{Kg})$.

\section{Washing procedures (AOAC, 2006):}

All glassware and vessels were thoroughly cleaned with deionized water and soaked in hot diluted nitric acid $(10 \%)$ for 24 hours and rinsed several times with deionized water and dried to ascertain that all the equipments were metal free.

\section{Digestion technique (Nnadozie et al., 2014):} Each sample $(2 \mathrm{~g})$ was treated with $10 \mathrm{ml}$ Nitric acid $(97 \%)$ and $2 \mathrm{ml}$ perchloric acid $(72 \%)$ and heated in a fume cupboard for 10 -15 minutes until the brown fumes disappeared and white fumes came out which indicated complete digestion.

\section{Preparation of blank and standard solutions:}

Blank and standard solutions were prepared in the same manner as applied for wet digestion and by using the same chemicals (Belete et al., 2014). Blank solution consisted of 10 parts of nitric acid and 1 part of $\mathrm{H}_{2} \mathrm{O}_{2}$ then was diluted with 25 parts of deionized water and filtered.

\section{Analysis:}

The metal analysis was carried out in Food Analysis Center, Faculty of Veterinary Medicine. The digest, blanks and standard solutions were aspirated by Atomic Absorption Spectrophotometer (VARIAN, model AA240 FS, Australia) and analyzed for detection and measurement of $\mathrm{Pb}, \mathrm{Cd}$ and $\mathrm{Se}$.

\section{Quantitative determination of heavy metals:}

The concentrations of lead, cadmium and selenium in the examined samples were calculated according to the following equation described by Horwitz (2000):

$$
\mathrm{C}=\mathrm{R} \times(\mathrm{D} / \mathrm{W})
$$

$\mathrm{C}=$ concentration of element (wet weight) $(\mathrm{mg} / \mathrm{kg})$

$\mathrm{R}=$ reading of element concentration on digital scale of Atomic Absorbtion Spectrophotometer.

$\mathrm{D}=$ Dilution of prepared sample ( $\mathrm{ml})$.

$\mathrm{W}=$ Wight of sample (gram).

The concentration of each element in the blank solution was also calculated and subtracted from each analyzed sample to exclude any traces of metal that might be present in the used acids for digestion.

\section{Calculation of the baby consumption of infant formula}

According to the manufacturer's instructions for preparing a meal of infant drink, each $5 \mathrm{~g}$ of infant formula powder is approximately reconstituted with $50 \mathrm{ml}$ of warm previously boiled water.

For newly born infants (0-6 months), the amount of infant formula milk consumed daily is about 7 meals as recommended by most of manufacturers, in which each meal is about $110 \mathrm{ml}$. Therefore, infant consumes about $770 \mathrm{ml}$ prepared by $77 \mathrm{~g}$ of infant formula powder. 
In case of older infants ( $>6$ months) the amount of infant formula milk consumed daily is 5 meals. Each meal is comprised of $210 \mathrm{ml}$, so infant totally consumes about $1050 \mathrm{ml}$ daily which prepared by $105 \mathrm{~g}$ of infant formula powder.

\section{Calculation of Estimated Daily Intake (EDI)}

To estimate the daily metal intake from consumption of infant formula, means data analyzed in the present work combined with consumption data of infant formula obtained according to the manufacturer's instructions for preparation of infant drink. Comparison of Acceptable Daily Intake (ADI) value of heavy metals recommended by FAO/WHO (1989) with daily metals intake from consumption of infant formula was calculated.

$\mathrm{EDI}=\mathrm{D} \times \mathrm{L} / \mathrm{W}$

$\mathrm{D}=$ Daily concentration of infant formula by gram. $\mathrm{L}=$ Level of heavy metal concentration in examined sample by $\mathrm{mg} / \mathrm{kg}$.
$\mathrm{W}=$ Body Weight by $\mathrm{kg}$.

The daily consumption of infant formula was calculated according to the manufacturer's instructions for preparing the infant meal.

The newly born infant (0-6 months) body weight is $5 \mathrm{~kg}$, for older infants (> 6 months and up to 18 months old) is $8 \mathrm{~kg}$ according to infants body weight charts of the fundementals of Pediatrics Book of Faculty of Medicine - Assiut University (2007).

\section{Calculation of Estimated Weekly Intake (EWI)} $\mathrm{EWI}=\mathrm{EDI} \times 7$

\section{Evaluation:}

By comparing of the Estimated Daily Intake (EDI) and the Estimated Weekly Intake (EWI) with Provisional Tolerable Weekly Intake (PTWI) and Acceptable Daily Intake (ADI) in $\mathrm{mg} / \mathrm{kg}$ body weight.

\begin{tabular}{llll}
\hline Element & PTWI & ADI & Reference \\
\hline Lead & 0.025 & 0.0036 & WHO (2000) \\
\hline Cadmium & 0.007 & 0.001 & WHO -FAO (2001) \\
\hline Selenium & 0.0114 & 0.00163 & FSANZ (2002) \\
\hline
\end{tabular}

Statistical Analysis:

Statistical analysis was carried out using Graph Pad Prism 5 program of statistics.

\section{RESULTS}

Table 1: Incidence and levels of lead in infant formula samples.

\begin{tabular}{|c|c|c|c|c|c|c|}
\hline \multirow[t]{2}{*}{ Samples } & \multirow{2}{*}{$\begin{array}{c}\text { No. of } \\
\text { examined } \\
\text { samples }\end{array}$} & \multicolumn{2}{|c|}{$\begin{array}{l}\text { Positive } \\
\text { samples }\end{array}$} & \multicolumn{3}{|c|}{$\begin{array}{c}\text { Concentration } \\
(\mathrm{mg} / \mathrm{kg})\end{array}$} \\
\hline & & No. & $\%$ & Min. & Max. & Average \\
\hline $\begin{array}{l}\text { Infant formula } \\
\text { ( 0-6 months) }\end{array}$ & 35 & 21 & 60 & 0.01 & 0.271 & 0.067 \\
\hline $\begin{array}{l}\text { Infant formula } \\
\text { (above } 6 \text { months) }\end{array}$ & 35 & 17 & 48.6 & 0.010 & 0.156 & 0.036 \\
\hline
\end{tabular}

Table 2: Comparison of lead level in the positive infant formula samples with standard Maximum Permissible Limit (MPL).

\begin{tabular}{|c|c|c|c|c|c|c|}
\hline \multirow{2}{*}{ Samples } & \multirow{2}{*}{$\begin{array}{c}\text { No. of } \\
\text { positive } \\
\text { samples }\end{array}$} & \multirow{2}{*}{$\begin{array}{c}* \text { MPL } \\
(\mathbf{m g} / \mathbf{k g})\end{array}$} & \multicolumn{2}{|c|}{$\begin{array}{c}\text { Within } \\
\text { permissible limit }\end{array}$} & \multicolumn{2}{|c|}{$\begin{array}{c}\text { Above permissible } \\
\text { limit }\end{array}$} \\
\hline & & & No & $\%$ & No & $\%$ \\
\hline $\begin{array}{l}\text { Infant formula } \\
\text { (0-6 months) }\end{array}$ & 21 & 0.02 & 5 & 23.8 & 16 & 76.2 \\
\hline $\begin{array}{l}\text { Infant formula } \\
\text { (above } 6 \text { months) }\end{array}$ & 17 & 0.02 & 3 & 17.6 & 14 & 82.4 \\
\hline
\end{tabular}

MPL: Maximum Permissible Limit.

*According to Egyptian Standards (2010). 
Table 3: Comparison of Standard acceptable daily lead intake (ADI) with that estimated in infant formula samples.

\begin{tabular}{lcccc}
\hline Samples & \multirow{2}{*}{$\begin{array}{c}\text { *ADI } \\
(\mathbf{m g} / \mathbf{k g ~ b . w . )}\end{array}$} & \multicolumn{2}{c}{$\begin{array}{c}\text { EDI } \\
(\mathbf{m g} / \mathbf{k g ~ b . w . )}\end{array}$} \\
\cline { 3 - 5 } $\begin{array}{l}\text { Infant formula } \\
\text { (0-6 months) }\end{array}$ & 0.0036 & 0.015 & 4.2 & Max. \\
\hline $\begin{array}{l}\text { Infant formula } \\
\text { (above 6 months) }\end{array}$ & 0.0036 & 0.13 & 2.1 & 0.525 \\
\hline
\end{tabular}

ADI: Acceptable Daily Intake.

EDI: Estimated Daily Intake.

* According to WHO (2000).

Table 4: Comparison of standard Provisional Tolerable Weekly lead Intake (PTWI) with that estimated in infant formula samples (EWI).

\begin{tabular}{|c|c|c|c|c|}
\hline \multirow[t]{2}{*}{ Samples } & \multirow{2}{*}{$\begin{array}{c}\text { *PTWI } \\
\text { (mg/kg b.w.) }\end{array}$} & \multicolumn{3}{|c|}{$\begin{array}{c}\text { EWI } \\
(\mathrm{mg} / \mathrm{kg} \mathrm{b.w.}) \\
\end{array}$} \\
\hline & & Min. & Max. & Average \\
\hline $\begin{array}{l}\text { Infant formula } \\
\text { (0-6 months) }\end{array}$ & 0.025 & 0.105 & 29.4 & 7.546 \\
\hline $\begin{array}{l}\text { Infant formula } \\
\text { (above } 6 \text { months) }\end{array}$ & 0.025 & 0.91 & 14.7 & 3.675 \\
\hline
\end{tabular}

PTWI: Provisional Tolerable Weekly Intake.

EWI: Estimated Weekly Intake. *According to WHO (2000).

Table 5: Incidence and levels of cadmium in infant formula samples.

\begin{tabular}{lcccccc}
\hline \multirow{2}{*}{ Samples } & \multirow{2}{*}{$\begin{array}{c}\text { No.of examined } \\
\text { samples }\end{array}$} & \multicolumn{2}{c}{$\begin{array}{c}\text { Positive } \\
\text { samples }\end{array}$} & \multicolumn{3}{c}{$\begin{array}{c}\text { Concentration } \\
\text { (mg/kg) }\end{array}$} \\
\cline { 3 - 7 } & 35 & No. & \% & Min. & Max. & Average \\
\hline $\begin{array}{l}\text { Infant formula } \\
\text { (0-6 months) }\end{array}$ & 35 & 14 & 51.4 & 0.01 & 0.197 & 0.04 \\
\hline $\begin{array}{l}\text { Infant formula } \\
\text { (above 6 months) }\end{array}$ & 40 & 0.008 & 0.09 & 0.018 \\
\hline
\end{tabular}

Table 6: Comparison of cadmium level in the positive infant formula samples with Standard Maximum Permissible Limit (MPL).

\begin{tabular}{|c|c|c|c|c|c|c|}
\hline \multirow[t]{2}{*}{ Samples } & \multirow{2}{*}{$\begin{array}{c}\text { No. of } \\
\text { positive } \\
\text { samples }\end{array}$} & \multirow{2}{*}{$\begin{array}{c}* \text { MPL } \\
(\mathrm{mg} / \mathrm{kg})\end{array}$} & \multicolumn{2}{|c|}{$\begin{array}{c}\text { Within permissible } \\
\text { limit }\end{array}$} & \multicolumn{2}{|c|}{$\begin{array}{c}\text { Above permissible } \\
\text { limit }\end{array}$} \\
\hline & & & No. & $\%$ & No. & $\%$ \\
\hline $\begin{array}{l}\text { Infant formula } \\
\text { (0-6 months) }\end{array}$ & 18 & 0.02 & 5 & 27.8 & 13 & 72.2 \\
\hline $\begin{array}{l}\text { Infant formula } \\
\text { (above } 6 \text { months) }\end{array}$ & 14 & 0.02 & 6 & 42.9 & 8 & 57.1 \\
\hline
\end{tabular}

*According to Egyptian standards (2010).

Table 7: Comparison of standard acceptable daily cadmium intake (ADI) with that estimated in infant formula samples.

\begin{tabular}{lcccc}
\hline Samples & $\begin{array}{c}* \text { ADI } \\
(\mathbf{m g} / \mathbf{k g ~ b . w . )}\end{array}$ & Min. & \multicolumn{2}{c}{$\begin{array}{c}\text { EDI } \\
\text { (mg/kg b.w.) }\end{array}$} \\
\hline $\begin{array}{l}\text { Infant formula } \\
\text { (0-6 months) }\end{array}$ & 0.001 & 0.154 & 3.034 & 0.616 \\
\hline $\begin{array}{l}\text { Infant formula } \\
\text { (above 6 months) }\end{array}$ & 0.001 & 0.105 & 1.181 & 0.236 \\
\hline * According to WHO -FAO (2001) & & &
\end{tabular}


Table 8: Comparison of standard Provisional Tolerable Weekly cadmium Intake (PTWI) with that estimated in infant formula samples (EWI).

\begin{tabular}{lcccc}
\hline Samples & $\begin{array}{c}* \text { PTWI } \\
(\mathbf{m g} / \mathbf{k g ~ b . w . )}\end{array}$ & Min. & Max. & $\begin{array}{c}\text { EWI } \\
\text { (mg/kg b.w. })\end{array}$ \\
\cline { 3 - 5 } $\begin{array}{l}\text { Infant formula } \\
\text { (0-6 months) }\end{array}$ & 0.007 & 1.078 & 21.238 & 4.312 \\
\hline $\begin{array}{l}\text { Infant formula } \\
\text { (above 6 months) }\end{array}$ & 0.007 & 0.735 & 8.267 & 1.652 \\
\hline
\end{tabular}

* According to WHO -FAO (2001)

Table 9: Incidence and levels of selenium in infant formula samples.

\begin{tabular}{lcccccc}
\hline \multirow{2}{*}{ Samples } & $\begin{array}{c}\text { No. of } \\
\text { examined } \\
\text { samples }\end{array}$ & No. & $\%$ & Mositive samples & \multicolumn{3}{c}{ Concentration (mg/kg) } \\
\cline { 3 - 7 } & 35 & 35 & 100 & 0.001 & 0.022 & 0.009 \\
\hline $\begin{array}{l}\text { Infant formula } \\
\text { (0-6 months) }\end{array}$ & 35 & 35 & 100 & 0.001 & 0.015 & 0.006 \\
\hline $\begin{array}{l}\text { Infant formula } \\
\text { (above 6 months) }\end{array}$ & & & & & &
\end{tabular}

Table 10: Comparison of selenium level in infant formula samples with standard Maximum Permissible Limit (MPL).

\begin{tabular}{|c|c|c|c|c|c|}
\hline \multirow[t]{2}{*}{ Samples } & \multirow{2}{*}{$\begin{array}{c}* \text { MPL } \\
(\mathrm{mg} / \mathrm{kg})\end{array}$} & \multicolumn{2}{|c|}{$\begin{array}{c}\text { Within permissible } \\
\text { limit } \\
\end{array}$} & \multicolumn{2}{|c|}{ Above permissible limit } \\
\hline & & No./35 & $\%$ & No./35 & $\%$ \\
\hline $\begin{array}{l}\text { Infant formula } \\
(0-6 \text { months })\end{array}$ & 0.01 & 8 & 22.9 & 6 & 17.1 \\
\hline $\begin{array}{l}\text { Infant formula } \\
\text { (above } 6 \text { months) }\end{array}$ & 0.01 & 8 & 22.9 & 1 & 2.9 \\
\hline
\end{tabular}

* According to FSANZ (2002).

Table 11: Comparison of standard acceptable daily selenium intake (ADI) with that estimated in infant formula samples.

\begin{tabular}{lcccc}
\hline Samples & \multirow{2}{*}{$\begin{array}{c}* \text { ADI } \\
(\mathbf{m g} / \mathbf{k g ~ b . w . )}\end{array}$} & & \multicolumn{2}{c}{$\begin{array}{c}\text { EDI } \\
(\mathbf{m g} / \mathbf{k g} \text { b.w. })\end{array}$} \\
\hline $\begin{array}{llll}\text { Infant formula } \\
\text { (0-6 months) }\end{array}$ & 0.00163 & 0.015 & 0.339 & 0.139 \\
\hline $\begin{array}{l}\text { Infant formula } \\
\text { (above 6 months) }\end{array}$ & 0.00163 & 0.013 & 0.197 & 0.079 \\
\hline
\end{tabular}

* According to FSANZ (2002).

Table 12: Comparison of standard Provisional Tolerable Weekly selenium Intake (PTWI) with that estimated in infant formula samples (EWI).

\begin{tabular}{lcccc}
\hline Samples & $\begin{array}{c}* \text { PTWI } \\
(\mathbf{m g} / \mathbf{k g ~ b . w . )}\end{array}$ & Min. & $\begin{array}{c}\text { EWI } \\
\text { (mg/kg b.w. })\end{array}$ \\
\hline $\begin{array}{l}\text { Infant formula } \\
\text { ( 0-6 months ) }\end{array}$ & 0.0114 & 0.105 & 2.373 & 0.973 \\
\hline $\begin{array}{l}\text { Infant formula } \\
\text { ( above 6 months })\end{array}$ & 0.0114 & 0.091 & 1.379 & 0.553 \\
\hline
\end{tabular}

* According to FSANZ (2002). 


\section{DISCUSSION}

Heavy metals are considered the main toxic byproducts causing serious health hazard to human and animal populations through progressive irreversible accumulation in their bodies as a result of repeated consumption of small amounts of these elements (Wheaton and Lawson, 1985). One of dried milk infant formula is product based on cow's milk or other animals and/or other ingredients which have been proven to be suitable for infant feeding. The nutritional safety and adequacy of infant formula should be scientifically demonstrated to support normal growth and development of infants (ESPGHAN, 2005). Some of heavy metals like lead and cadmium enter in the food's chain naturally and they are unavoidable. Infants and young children are the most risky group to these metals. Lead is a known neurotoxin for infant, and can cause reduced Intelligence Quotient (IQ), learning disabilities and irreversibly effects development of the nervous system. Cadmium leads to kidney disfunction and has estrogenic propreties (Sadeghi et al., 2014).

Results recorded in Table 1 revealed that the incidence of lead in infant formula samples (0-6 months) was $60 \%$ with an average concentration of $0.067 \mathrm{mg} / \mathrm{kg}$ and $48.6 \%$ in infant formula samples (above 6 months) with an average concentration of $0.036 \mathrm{mg} / \mathrm{kg}$ which exceed the Maximum Permissible Limit $(0.02 \mathrm{mg} / \mathrm{kg})$ recommended by Egyptian Standards (2010).

The obtained results were in harmony with that indicated by Amer and Aiad (2012), and lower than that of Riolfatti and Veronese (1990); De Castro et al. (2010); Salah (2012); Mohammed et al. (2013); El-Leboudy et al. (2017) but higher than Dabeka et al. (2011); Mehrina and Bashti (2014).

Lead piping and lead-lined tanks of water supplies are the sources of lead contamination. Lead, due to its wide use in industrial processes, ranks as the metal of largest diffusion through the atmosphere; one could speculate that this could in part explain the relatively high concentration found (Carl, 1991; Okada et al., 1997).

The high lead level in the examined samples may be attributed to the fact that the migration of lead from the surface of the can to the products (Ramonaityte, 2001).

Results recorded in Table 2 showed that 5 (23.8\%) of infant formula samples (0-6 months) were within permissible limit according to the Egyptian Standards (2010) $(0.02 \mathrm{mg} / \mathrm{kg})$ and $16(76.2 \%)$ of Infant formula samples (0-6 months) were above permissible limit. Also, 3 (17.6\%) of infant formula samples (above 6 months) were within permissible limit and $14(82.4 \%)$ of Infant formula samples (above 6 months) were above permissible limit.

Table 3 showed the estimated daily intake (EDI) of lead in infant formula samples compared by standard acceptable daily Lead intake (ADI) $0.0036 \mathrm{mg} / \mathrm{kg}$ b.w. recommended by WHO (2000). The average of EDI for infant formula samples (0-6 months) was $1.078 \mathrm{mg} / \mathrm{kg}$ b.w. and for Infant formula samples (above 6 months) was $0.525 \mathrm{mg} / \mathrm{kg} \mathrm{b.w.} \mathrm{These}$ results are higher than Tripathi et al. (1999); Alkhalifa and Dilshad (2010).

Results in Table 4 discussed the estimated Weekly Intake of Lead in infant formula samples (EWI) compared to the standard Provisional Tolerable Weekly Lead Intake (PTWI) recommended by WHO (2000) $0.025 \mathrm{mg} / \mathrm{kg}$ b.w. Average of EWI for infant formula samples (0-6 months) was 7.546 $\mathrm{mg} / \mathrm{kg} \mathrm{b.w}$. and for infant formula samples (above 6 months) was $3.675 \mathrm{mg} / \mathrm{kg}$ b.w. These results exceeded the standard Provisional Tolerable Weekly Lead Intake. While Ikem et al. (2002) recorded low estimated Weekly Intake of Lead in infant formula samples $0.025 \mathrm{mg} / \mathrm{kg}$ b.w. while Kazi et al. (2009) revealed that the estimated intakes of lead as $\mu \mathrm{g} / \mathrm{kg} /$ week for infants ( $>1$ year) through milk formulae is below the recommended tolerable levels.

The kinetics of many metals is age-specific, with a higher gastrointestinal absorption, less effective renal excretion as well as a less effective blood-brain barrier in newborns compared to adults. Due to their low body weight and high food consumption per $\mathrm{kg}$ of body weight, the tissue levels of contaminants can reach higher levels in newborns than in adults Oskarsson et al. (1998).

Regarding the data recorded in Table 5, it is evident that the incidence of Cadmium in infant formula samples (0-6 months) was $51.4 \%$ and contained an average concentration Cadmium of $0.04 \mathrm{mg} / \mathrm{kg}$ which exceeds the Maximum Permissible Limit $(0.02 \mathrm{mg} / \mathrm{kg})$ recommended by Egyptian standards (2010) while $40 \%$ of infant formula samples (above 6 months) had an average concentration of 0.018 $\mathrm{mg} / \mathrm{kg}$ which is in a match to the Maximum Permissible Limit.

These results were higher than those obtained Riolfatti and Veronese (1990); Rodriguez et al. (1999); Alkhalifa and Dilshad (2010). The obtained results were in harmony with those of Amer et al. (2006); De Castro et al. (2010); Amer and Aiad (2012), while lower than those of Jannat et al. (2009).

Contamination of milk and milk prouducts during storage, marketing and leaching from containers may be considered as a source of $\mathrm{Cd}$ in milk and 
other dairy products. The distribution change of $\mathrm{Cd}$ after heat treatment of milk due to the formation of complexes between the whey proteins and the metal or to the desegregation of the $\mathrm{Cd}$ bound to casein micelles. (Cabrera et al., 1995; Okada et al., 1997).

Concerning the results recorded in Table 6 , it showed that $5(27.8 \%)$ of infant formula samples (06 months) were within the permissible limit and 13 $(72.2 \%)$ were above permissible limit. While 6 (42.9\%) of Infant formula samples (above 6 months) were within the permissible limit and 8 (57.1\%) were above the permissible limit.

Table 7 showed that the estimated daily intake (EDI) of cadmium in infant formula samples compared to the standard acceptable daily cadmium intake (ADI) $0.001 \mathrm{mg} / \mathrm{kg}$ b.w. recommended by WHO-FAO (2001). The average of EDI for infant formula samples (0-6 months) was $0.616 \mathrm{mg} / \mathrm{kg} \mathrm{b.w}$. and for infant formula samples (above 6 months) was 0.236 $\mathrm{mg} / \mathrm{kg}$ b.w. These results indicated that both formulas exceeded the acceptable daily cadmium intake. Lower results were recorded by Tripathi et al. (1999); Alkhalifa and Dilshad (2010).

Likewise results in Table 8 discussed the estimated Weekly Intake of cadmium in infant formula samples (EWI) compared to the Standard Provisional Tolerable Weekly cadmium Intake (0.007 mg/kg b.w.) recommended by WHO-FAO (2001). The average of EWI for infant formula samples (0-6 months) was $4.312 \mathrm{mg} / \mathrm{kg} \mathrm{b.w}$. and for infant formula samples (above 6 months) was 1.652 $\mathrm{mg} / \mathrm{kg}$ b.w. These results exceeded Standard Provisional Tolerable Weekly cadmium Intake. Ikem et al. (2002) recorded lower results (0.07 $\mathrm{mg} / \mathrm{kg}$ b.w.) and Kazi et al. (2009) revealed that the estimated intakes of cadmium as $\mu \mathrm{g} / \mathrm{kg} /$ week for infants (>1 year) through milk formulae is below the recommended tolerable levels.

Results recorded in Table 9 revealed that the incidence of selenium in infant formula samples (0-6 months) was $100 \%$ with an average concentration of $0.009 \mathrm{mg} / \mathrm{kg}$ and $100 \%$ in infant formula samples (above 6 months) with an average concentration of $0.006 \mathrm{mg} / \mathrm{kg}$ which agreed with the Maximum Permissible Limit $(0.01 \mathrm{mg} / \mathrm{kg})$ according to FSANZ (2002). These results are higher than Kumpulainen et al. (1987) and lower than Al-Saleh and Al-Doush (1997). The results were in harmony with Oveisi et al. (2002) and Khan et al. (2013).

Comparing the results with the MPL (Table 10) showed that $22.9 \%$ of infant formula samples (0-6 months) were within permissible limit and $17.1 \%$ of Infant formula samples (0-6 months) were above permissible limit. For infant formula samples (above 6 months) $22.9 \%$ were within permissible limit and
$2.9 \%$ were above permissible limit. That mean most of samples were below permissible limit.

The deficiency or excess of Se could promote several clinical disorders resulting public health problems, as respiratory system cancer, skin disorder, anemia, depression of growth, impaired reproductive performance, heart failure and gastrointestinal disturbances, fatigue, decreased immunity and even death (Fraga, 2005). Se deficiency in infants, especially preterm infants, have reported that the condition might cause growth retardation and acute diseases in childhood as well as potentially long-term negative outcomes in adults (Vanek, 2015).

Selenium is essential to humans, in that it helps maintain cell membrane integrity and has an antioxidant role in the body. Selenium deficiency can lead to diseases such as Keshan disease and Kaschin-Beck disease. Both diseases have been reported in selenium-deficient areas, such as parts of China (ANZFA, 1999).

Signs and symptoms of selenosis include a garlic odor on the breath, gastrointestinal disorders, hair loss, sloughing of nails, fatigue, irritability, and neurological damage. Extreme cases of selenosis can exhibit cirrhosis of the liver, pulmonary edema, or death (Public Health Statement, 2009).

Data in Table 11 point out the estimated daily intake (EDI) of selenium in infant formula samples compared to the standard Acceptable Daily selenium Intake $(0.00163 \mathrm{mg} / \mathrm{kg} \quad$ b.w.) recommended by FSANZ (2002). The average of EDI for infant formula samples (0-6 months) was $0.139 \mathrm{mg} / \mathrm{kg}$ b.w. and for infant formula samples (above 6 months) was $0.079 \mathrm{mg} / \mathrm{kg}$ b.w.

Moreover, results in Table 12 discussed the estimated Weekly Intake of selenium in infant formula samples (EWI) compared to the Standard Provisional Tolerable Weekly selenium Intake (0.0114 mg/kg b.w.) recommended by FSANZ (2002). The average of EWI for infant formula samples (0-6 months) was $0.973 \mathrm{mg} / \mathrm{kg} \mathrm{b.w}$. and for infant formula samples (above 6 months) was 0.553 $\mathrm{mg} / \mathrm{kg}$ b.w. These results exceeded Standard Provisional Tolerable Weekly selenium Intake.

\section{CONCLUSION}

The present study revealed that infant formula contains heavy metals (lead and cadmium) in variable concentrations above the toxicity levels. The possible sources of this contamination are the raw materials used in production, poor quality production processes and adulteration of infant foods or from contamination of the original cow's 
milk, which may be due to exposure of lactating cow to environmental pollution or consumption of feeding stuffs and water. Moreover, raw milk may be exposed to contamination during its manufacture. Contamination may also occur from the use of aluminum utensils and cans in milk and dairy products. Therefore, to lower the lead and cadmium content in infant formula, it is important to avoid these sources of contamination.

This study revealed that infant formula contain selenium in variable concentrations almost below the permissible limit. It is very important that infant formula contain selenium in the amount allowed to prevent any harm due to increasing or decreasing of selenium. The average of estimating daily intake (EDI) values for infant formula (0-6 months) samples was $0.139 \mathrm{mg} / \mathrm{kg} \mathrm{b.w.} \mathrm{and} \mathrm{for} \mathrm{infant}$ formula (above 6 months) samples was $0.079 \mathrm{mg} / \mathrm{kg}$ b.w. which compared by acceptable daily selenium intake (ADI). In order to minimize the hazardous effect of these pollutants, the following recommendations should be applied:

- Care should be taken in dairy factories during production phase to avoid contamination of infant formula by using utensils made from stainless-steel.

- Periodic water analysis should be applied by the agencies concerned with water purification to make sure that water used is safe, clean and contain the permissible limits of heavy metals.

- Minimize the environmental pollution and hygienic disposal of industrial effluents.

- Hazard Analysis Critical Control Point (HACCP) has an important role for preventing and controlling chemical contaminants of infant formula.

- Reconstitution of infant formula with boiled mineral water if possible.

- It's preferable that consumption the infant formula should be as early as possible from the date of manufacture to reduce the migration of heavy metals from container to the products during storage periods.

- Infant formula manufacturers should make efforts to strive to reduce heavy metals concentration in their products and print the maximum lead and cadmium contents on the package.

- Manufacturers should also state the possible dangers particularly in nursing infants with renal insufficiency or other in disorders or characteristics that might favor accumulation of these elements.

\section{REFERENCES}

Ahmad, W.M.S. (2002): Studies on heavy metals pollution in poultry farms in relation to production performance. Ph. D. Thesis, Fac. of Vet. Med. Zagazig Univ. Egypt.

Akhter, P.; Baloch, N.Z.; Mohammad, D.; Orfi, S.D. and Ahmad, N. (2004): Assessment of strontium and calcium levels in Pakistani diet. Journal of Environmental Radioactivity 73: 247-256.

Alkhalifa, A. and Dilshad, A. (2010): Determination of key elements by ICP - OES commercially available infant formulae and baby foods in Saudi Arabia. Afr. J. Food Sci., 4: 464-468.

Al-Saleh and Al-Doush (1997): Selenium levels in infant milk formula. BioMetals, 10: 299-302.

Amer, A.A. and Aiad, A.S. (2012): Lead and cadmium levels in some dried dairy products. Alex. J. Vet. Sci., 36(1): 99-106.

Amer, I.H.; Awad, E.I. and Abd-El Aal, S.F. (2006): Prevalence of heavy metal residues in some basic infant diet. $8^{\text {th }}$ Sci. Vet. Med. Zag, Conference, 31 Aug-3 Sep, 2006.

Anderson, O. and Nielsen, J.B. (1993): Effects of simultaneous low level dietary supplementation with inorganic and organic Se on blood and organ toxic levels of metals in mice. J Trace Electrolytes Health Dis 7(2), 122.

Association of Official Analytical Chemists " $A O A C$ " (2006): Official Methods of Analysis. 31th Ed., W. Horwitz (Editor), Academic Press, Washington, D. C., USA.

ANZFA Australia New Zealand Food Authority, (1999): Contaminants in foods-metals, full assessment report, Proposal P157, ANZFA, Canberra.

Belete, T.; Hussen, A. and Rao, V. (2014): Determination of Concentrations of Selected Heavy Metals in Cow's Milk: Borena Zone, Ethiopia. J. Health Sci., 4(5): 105-112.

Cabrera, C.; Lorenzo, M. and Lopez, M. (1995): Lead and cadmium contamination in dairy products and its repercussion on total dietary intake. J. Agr. and Food Chem., 43(6): 16051609.

Cambra, K. and Alonso, E. (1995): Blood lead levels in 2-to 3-years-old children in the Greater Bilbao Area (Basque Country, Spain): relation to dust and water lead levels. Archives of Enviromental Health: An International Journal, 50(5): 362-366.

Carl, M. (1991): Heavy metals and other trace elements. Monograph on residues and contaminants in milk and milk products. Special Issue. 9101: 112-119.

Dabeka, R.; Fouquet, A.; Belisle, S. and Turcotte, S. (2011): Lead, cadmium and aluminum Canadian infant formulae,oral electrolytes 
and glucose solutions. Food Add. Conta., 28: 744-753.

De Castro, C.; Arruda, A.; Da Cunha, L.R.; SouzaDe, J.R.; Braga, J.W.B. and Dórea, J.G. (2010): Toxic metals (Pb and $\mathrm{Cd}$ ) and their respective antagonists $(\mathrm{Ca}$ and $\mathrm{Zn})$ in infant formulas and milk marketed in Brasilia, Brazil. Int. J. Environ. Res. Public Health, 7: 4062-4077; doi:10.3390/ijerph7114062.

De Voto, E. and Yokel, R.A. (1994): The biological speciation and toxicokinetics of aluminum. Enviromental Health Perspectives, 102(11): 940.

Egyptian Standards (2010): Maximum levels of heavy metal contaminants in food. Egyptian organization for standardization No. 7136.

El-Leboudy, A.; Amer, A.A.; Abo El-Makarem, H.S. and Abo Hadour, H. (2017): Heavy metals residues in some dairy products. AJVS, 52(1): 334-346.

European Society of Paediatric Gastroenterology, Hepatology and Nutrition (ESPGHAN) (2005): Global standard for the composition of infant formula: recommendations of an ESPGHAN Coordinated International Expert Group. Pediatric Gastroenterology and Nutrition, 41:584-599.

FAO/WHO, Joint Expert Committee on Food Additives, WHO Technical Report Series No. 505 (1972); No. 555 (1974c); No.647 (1980); No.683 (1982); No. 751 (1987) and No. 776 (1989): Evaluation of certain food additives and contaminants, Geneva.

Fraga, C.G. (2005): Relevance, essentiality and toxicity of trace elements in human health. Molecular Aspects of Medicine, 26: 235-244.

Food Standards Australia New Zealand (FSANZ) (2002): Food Standards Australia New Zealand Canberra. Retrieved from (www.foodstandards.gov.au). Accessed at 812-2018.

Hatano, S.; Nishi, Y. and Usui, T. (1984): Plasma selenium concentration in healthy Japanese children and adults determined by flameless atomic absorption spectrophotometry. J. Pediatr Gastroenterol., 3, 426-431.

Helzlsouer, K.J.; Comstock, G.W. and Morris, J.S. (1989): Selenium, lycopene, alphatocopherol, beta-carotene, retinol and subsequent bladder cancer. Cancer Res 49, 6144-6148.

Higharm, A.M. and Tomkins, R.P.T. (1993): Determination of trace quantities of selenium and arsenic in canned tuna fish by using electroanalytical techniques. Food chemistry 48: 85-93.

Horwitz, W. (Ed.) (2000): Official Methods of Analysis of AOAC International. $17^{\text {th }} \mathrm{Ed}$., Vol. (1). AOAC International, Suite 500, 481
Nourth Frederick Avenue, Gaithersburg, Maryland 20877-2417 USA.

Ikem, A.; Nwankwoala, A.; Odueyungbo, S.; Nyavor, K. and Egiebor, N. (2002): Levels of 26 elements in infant formula from USA, UK, and Nigeria by microwave digestion and ICPOES. Food Chem., 77: 439-447.

Jannat, B.; Sadeghi, N.; Oveisi, M.R.; Behfar, A.; Komeilizadeh, H. and Shafaati, A. (2009): Simultaneous determination of lead, cadmium, copper and zinc in Infant formula by anodic stripping voltammetry. Iran. J. Pharmaceut. Res., 8 (3): 159-162.

Karadjova, I.; Girousi, S.; Iliadou, E. and Stratis, I. (2000): Determination of $\mathrm{Cd}, \mathrm{Co}, \mathrm{Cr}, \mathrm{Cu}, \mathrm{Fe}$, $\mathrm{Ni}$ and $\mathrm{Pb}$ in milk, cheese and chocolate. Mikrochimica Acta 134: 185-191.

Kazi, T.G.; Jalbani, N.; Baig, J.A.; Kandhro, G.A.; Afridi, H.I.; Arain, M.B.; Jamali, M.K. and Shah, A.Q. (2009): Determination of toxic elements in infant formulae by using electrothermal atomic absorption spectrometer. Food Chem. Toxicol., 47: 1425-1429.

Khan, N.; Jeong, I.S.; Hwang, I.M.; Kim, J.S. and Choi SH, et al. (2013): Method validation for simultaneous determination of chromium, molybdenum and selenium in infant formulas by ICP-OES and ICP-MS. Food Chem, 141: 3566-3570.

Korpela, H. (1993): Selenium in cardiovascular diseases. J Trace Elem. Electrolytes Health Dis, 7, 115.

Kumpulainen, J.; Salmenpera, L. and Siimes M.A, et al. (1987): Formula feeding results in lower selenium status than breast-feeding or selenium supplemented formula feeding: a longitudinal study. Am. J. Clin. Nutr., 45: 49-53.

Licata, P.; Trombetta, D.; Cristani, M.; Giofre, F.; Martino, D.; Calo, M. and Naccari, F. (2004): Levels of toxic and essential metals in samples of bovine milk from various dairy farms in Calabria, Italy. Env. Int. (30): 1-6.

Litov, R.E.; Sickles, V.S. and Chan, G.M.; et al. (1987): Selenium and glutathione perioxidase status in term infants fed human milk, wheybased, or soy-based infant formula. Am. J. Clin. Nutr., 45, 836.

Lombeck, I. (1980): The clinical significance of trace elements in childhood. Erg Inn Med Kinderh., 44, 1-35.

Lopez-Garcia, I.; Viñas, P.; Romero-Romero, R. and Hernandez-Cordoba, M. (2009): Ion exchange preconcentration and determination of vanadium in milk samples by electrothermal atomic absorption spectrometry. Talanta Journal 78: 1458-1463.

Martino, F.A.R.; Sanchez, M.L.F. and Medel, A.S. (2000): Total determination of essential and 
toxic elements in milk whey by double focusing ICP-MS. Analytical Atomic Spectrometry, 15: 163-168.

Masten, S. (2000): Aluminum compounds, Review of Toxicological Literature Abridged Final Report. Integrated Laboratory Systems, North Carolina, 27709

Mehrina, M.A. and Bashti, A. (2014): Evaluation of toxic element contents in infant foods commercially available in Iran. Academy for Enviro and Life Sci, India, 3 (6): 249-253 23(2): 62-65

Mohammed, A.G.; Khadir, E.K.; Abubakar, M.; Waleed, A. and WeiZhao, C. (2013): Evaluation of some physicochemical parameters of three commercial milk products. PAK. J. Food Sci., 23(2): 62-65.

Nnadozie, C.; Yauri, U. and Muhammad, C. (2014): Assessment of some dairy products sold in Sokoto Metropolis, Nigeria. Inter. J. Adv. Res. Chem. Sci. "IJARCS", 1 (10): 31-37.

Okada, I.A.; Sakuma, A.M.; Maio, F.D.; Dovidauskas, S. and Zenebon, O. (1997): Evaluation of lead and cadmium levels in milk due to environmental contamination in the Paraiba Valley region of Southeastern Brazil. Journal of Public Health 31(2): 140143.

Orak, H.; Altun, M. and Ercag, E. (2005): Survey of heavy metals in Turkish white cheese. Italian Journal of Food Science 17: 95-100.

Oskarsson, A.; Palminger Hallen, I.; Sundberg, J. and Petersson Graw, K. (1998): Risk assessment in relation to neonatal metal exposure. Analyst, 123: 19-23.

Oveisi, M.R.; Jannat, B.; Shafaati, A.R. and Hamedi, $M$. (2002): Determination of selenium in infant formula by DPCSV. Daru. 10: 28-33.

Protasowicki, M. (1992): Heavy metals content in the selected food. Proceedings of 3rd World Congress, Food born infection and intoxication, Berlin.

Public Health Statement (2009): Health Effects" (PDF). Agency for Toxic Substances and Disease Registry. Retrieved http://www. atsdr.cdc.gov/toxprofiles/tp92-c3. Accessed 27-1-2019.

Ramonaityte, D.T. (2001): Copper, Zinc, Tin And Lead In Canned Evaporated, Produced In Lithuania: The Initial Content and Tin Change At Storage Food Add. And Contm., 18(1): 31-37.

Riolfatti, M. and Veronese, M. (1990): Heavy metals in milk formulas. Igiene-Moderna, 93 (6): 1090-1100.

Rodriguez, E.M.; Delgado, U.E. and Diaz, R.C. (1999): Concentration of cadmium and lead in different types of milk. Food Res. And Tenchnol., 208 (3): 162-168.

Sadeghi, N.; Oveisi, M.R.; Jannat, B.; Shafaati, A.R. and Hamedi, M. (2014): Simultaneous measurement of zinc, copper, lead and cadmium in baby weaning food and powder milk by DPASV. Iran. J. pharm. Res., 13(1):345-349.

Salah, F. (2012): Assessment of toxic heavy metals in some dairy products and the effect of storage on its distribution. J. Ame. Sci., 8(8): 665-670.

Tripathi, R.M.; Raghunath, R.; Sastry, U.N. and Krishnamoorthy, T.M. (1999): Daily intake of heavy metals by infants through milk and milk products. Sci. Total Environ., 227 (23): 229-235.

Vanek, V.W. (2015): Review of trace mineral requirements for preterm infants: what are the current recommendations for clinical practice? Nutr Clin Pract.; 30:720-1. doi: 10. $1177 / 0884533615598965$.

Wheaton, F. and Lawson, T. (1985): Processing of aquatic food product. A Wiley Interscience Publication, PP. 231-232. Jhon Wiley, New York, Toronto.

WHO (World Health Organization) (2000): Safety evaluation of certain food additives and contaminants: Lead. WHO Food Additives, Series 44.

WHO-FAO (2001): Meeting of the Joint FAO/WHO Expert Committee On Food Additives. Geneva: World Health Organization. 


\section{تقدير مستويات الرصاص والكادميوم والسيلينيوم فى بعض الألبان الجافه المباعه بالاسواق}

\section{احمد عبل الحميل /حد ، ولاء فاروق /مين ، منال محمد /مين ، رشا فوزي عيا}

\section{E-mail: manalamin727@yahoo.com Assiut University web-site: www.aun.edu.eg}

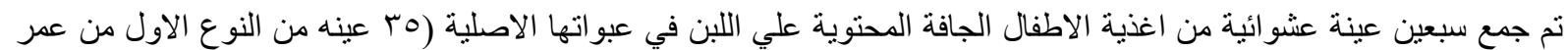

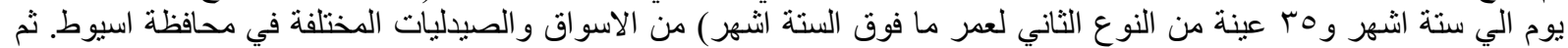

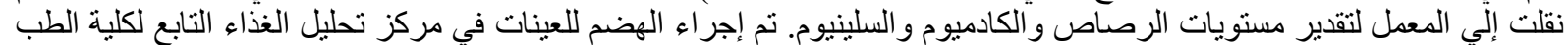

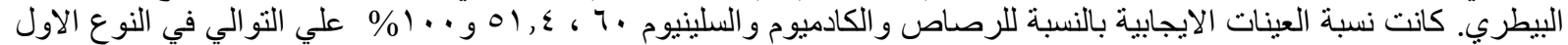

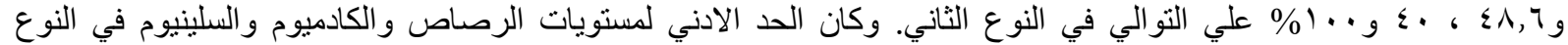

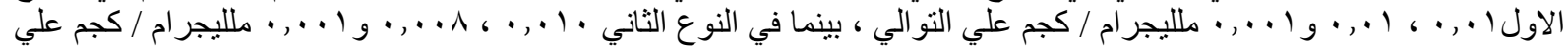

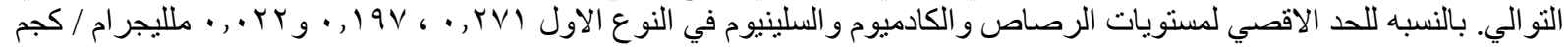

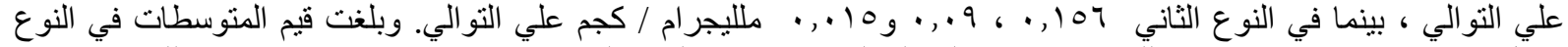

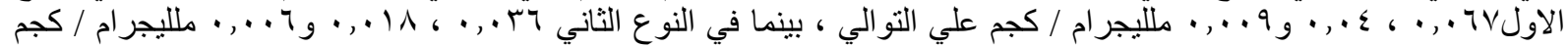

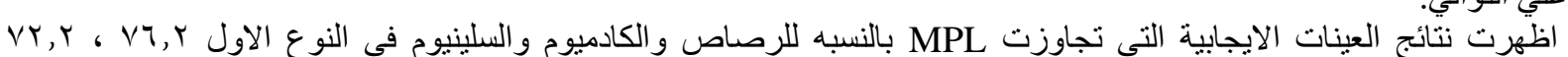

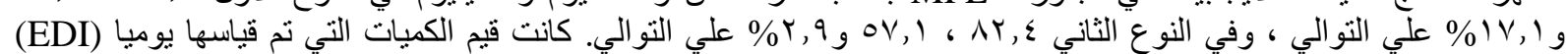

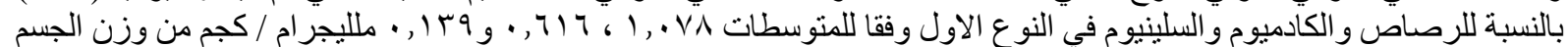

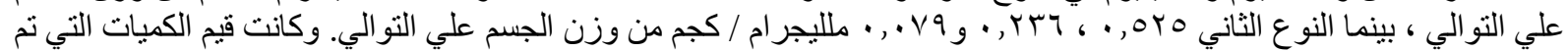

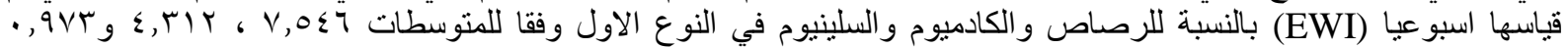

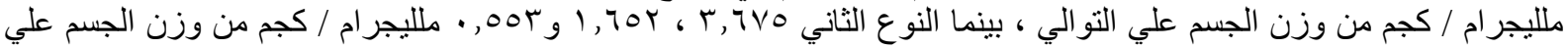

